JFFI. 2018; 5(2) 279-283

www.jurnal.farmasi.umi.ac.id/index.php/fitofarmakaindonesia

\title{
UJI IN VITRO DAN IN SILICO SENYAWA 5,7,2',5'-TETRAHYDROXY FLAVAN-3-OL TERHADAP ENZIM ALPHA GLUCOSIDASE
}

\author{
Frengki $^{1,2^{*}}$, Deddi Prima ${ }^{3}$, Fatma Sri Wahyuni ${ }^{3}$, Daan Khambri ${ }^{1}$, Henny Vanda ${ }^{2}$, Noni \\ Zakiah $^{4}$, Jamilah Abbas ${ }^{5}$, Berna Elya ${ }^{6}$ \\ ${ }^{1}$ Biomedik Fakultas Kedokteran Universitas Andalas-Padang \\ ${ }^{2}$ FKH Universitas Syiah Kuala-Banda Aceh \\ ${ }^{3}$ Fakultas Farmasi Universitas Andalas \\ ${ }^{4}$ Akademi Farmasi-Aceh Besar \\ ${ }^{5}$ LIPI-Kimia Puspitek-Serpong \\ ${ }^{6}$ Fakultas Farmasi Universitas Indonesia \\ *farhanayyash@gmail.com, frengki_fkh@unsyiah.ac.id
}

\begin{abstract}
Several of Calophyllums genus have been searched and proven as medicinal plants and Calophyllum macrophyllum is one of its genus. We have been isolated a compound from ethyl acetate fraction of the stem-bark. The compound was flavan-3-ol (5,7,2',5'-tetrahydroxy flavan-3-ol). This research aimed to determine inhibition antidiabetic activity and affinity of its compound on a-glycosidase enzyme. In vitro antidiabetic effect shown by $I_{50}$ $9.10 \mu \mathrm{g} / \mathrm{ml}$ and docking by Arguslab 4.01 shown by $\Delta G-10,24 \mathrm{kkal} / \mathrm{mol}$ as in silico test. The inhibition activity of flavan-3-ol against the $\alpha$-glucosidase enzyme that is very strong shows its promising potential as a candidate for antidiabetic drugs.
\end{abstract}

Keywords: Flavan-3-ol, alpha glukosidase, in vitro, in silico

\section{PENDAHULUAN}

Kepercayaan masyarakat terhadap manfaat dan kegunaan tumbuhan dalam pengobatan dan pemeliharaan kesehatan semakin meningkat (Christine,1985). Salah satu genus tumbuhan tingkat tinggi Indonesia yang mempunyai potensi sebagai sumber senyawa kimia bioaktif adalah Calophyllum dari suku Guttiferae/Clussiaceae. Beberapa wilayah seperti Sumatera, Jawa Barat, Jawa Tengah, Kalimantan dan Papua merupakan tempat penyebarannya. Selain di Indonesia tumbuhan genus Calophyllum ini juga ditemukan di Vietnam, Kamboja, Thailand, Singapura, Australia bagian selatan, pulau Andaman, dan Srilangka dengan 200 jenis telah teridentifikasi (Soerjanegara. 1994; Backer. 1963; Heyne. 1987).

Beberapa jenis Calophyllum diantaranya adalah C. macrophyllum Scheff, C. teysmannii, $C$. inophyllum, C. apetalum, C. moonii, C. lankaensis, C. caledonicum, C. cordata-oblongum, C. verticillatum, C. calaba, C. brasiliense, C. blancoi, C. australianum FvM, C. enervosu, C. insularum dan C. gracilipes.

Kumarin, santon, flavonoid, biflavonoid, triterpenoid, asam-asam organik dan senyawa benzofenon merupakan senyawa aktif yang berhasil diisolasi dari genus Callophyllum (Cao S-G, et al. 1998; Yimdjo, et al. 2004; Taher, et al. 2005; Kirk, et al. 1994).

Senyawa santon ((+) kalanolida A) dari $C$. lanigerum mempunyai aktivitas sebagai antiplatelet, antibakteri, antikembung dan anti-HIV (Dharmaratne, et al. 1999, Linuma, et al. 1996). Senyawa kumarin (brasimarin A, B, dan C, 4fenilkumarin dari kulit batang $C$. brasiliense) bersifat antitumor (Ito, T. 2003). Senyawa poliisoprenil keton (enervosanon) dari kulit batang C. enervosum dilaporkan aktif sebagai antibakteri terhadap bakteri B. subtilis (ATCC 6633), E. coli (ATCC 25922), P. aeruginosa dan S. aureus (ATCC 6538) (Taher, et al. 2005). Senyawa golongan triterpena friedelin dan asam protokatekuat dan asam shikimat dari daun $C$. brasiliense aktif sebagai anti-HIV (Reyes-Chilpa, et $a l$. 2004). Golongan flavonoid juga ditemukan dari $C$. calaba berupa senyawa biflavonoid amentoflavon dan merelloflavon, dari C. inophyllum ditemukan senyawa katekin (Linuma, et al. 1994).

Peneliti juga berhasil mengisolasi senyawa flavanal $\left(5,7,2^{\prime}, 5^{\prime}\right.$-tetrahydroxy flavan-3-ol) dari kulit batang tumbuhan C. macrophyllum Scheff. Senyawa ini memiliki aktivitas antioksidan yang lebih kuat dibandingkan dengan katekin. Diduga 
gugus -OH posisi para pada cincin B senyawa flavan3 ol ini berperan meningkatkan aktivitas antioksidan lebih kuat dibanding kuersetin yang memiliki rantai samping gugus -OH posisi meta (Frengki, 2011)

Senyawa ini diduga juga aktif sebagai obat antidiabetes sebagaimana kuersetin sesama golongan flavonoid yang memiliki gugus fenol. Sutedja et al, (2003) melaporkan semua bahan alam yang mengandung senyawa dengan gugus fenol berkhasiat sebagai obat antidiabetes. Oleh karena itulah peneliti tertarik melakukan uji antidiabetes secara in vitro melalui mekanisme inhibisi enzim $\alpha$ glucosidase. Lebih jauh hasil uji in vitro ini akan dikonfirmasi secara in silico melalui metode docking moleculer.

\section{METODE PENELITIAN}

\section{A. Bahan dan Alat}

Enzim $\alpha$-glukosidase (Saccharoyces sp., Oriental Yeast Co., Ltd., Jepang), bovine serum albumin (Wako pure Chemical Industries, Ltd, Jepang.), koji, paranitrofenil $\alpha$-D-glukopiranosa (PNP) (Wako pure Chemical Industries, Ltd., Jepang), $\mathrm{Na}_{2} \mathrm{CO}_{3}$ (Merck cat. 1.09940, Jerman).

Peralatan uji in vitro meliputi pipet mikro (Eppendrof), lemari pendingin, wadah inkubator, tube berbagai ukuran (pyrex) dan rak tabung reaksi. Sedangkan perlengkapan uji in silico yang digunakan dalam penelitian ini adalah perangkat keras berupa PC dengan Random Access Memory sebesar 2 GB. Perangkat lunak yang digunakan berupa Pymol, UCSF Chimera, Arguslab, VegaZZ, dan Chemdraw 2006.

\section{B. Prosedur Penelitian}

1. Uji Antidiabetes terhadap enzim $\alpha$-glukosidase (Dewi et al, 2007)

Larutan sampel dalam $5 \mu \mathrm{L}$ DMSO ditambah dengan $495 \mu \mathrm{L}$ dapar fosfat $0,1 \mathrm{M}$ dan 250 $\mu \mathrm{L}$ 0,02M p-nitrofenil $\alpha$-D-glukopiranosa (PNP), sampel diinkubasi selama 5 menit pada suhu $37^{\circ} \mathrm{C}$. Kedalam sampel ditambahkan $250 \mu \mathrm{L}$ larutan enzim $\alpha$-glukosidase, diinkubasi lagi selama 15 menit pada suhu $37^{\circ} \mathrm{C}$. Setelah masa inkubasi selesai

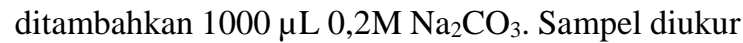
absorbansinya dengan spektrofotometer UV-Vis pada panjang gelombang $400 \mathrm{~nm}$. Perlakuan yang sama juga dilakukan pada standar kuersetin, sedangkan blanko sampel tanpa penambahan larutan enzim diganti dengan penambahan $250 \mu \mathrm{L}$ dapar fosfat $\mathrm{pH} \mathrm{7,} \mathrm{demikian} \mathrm{juga} \mathrm{blanko} \mathrm{(tanpa} \mathrm{sampel)}$ hanya digunakan larutan DMSO.

Nilai $\mathrm{LC}_{50}$ ditentukan melalui persamaan regresi dengan bantuan program komputer sederhana Mic. Excel.
2. Uji in silico terhadap enzim $\alpha$-glukosidase (Ragno et al. 2009)

Struktur 3 dimensi ligan dibuat melalui program Chemdraw 2006, struktur tersebut disimpan dalam format pdb. Kemudian dilakukan minimisasi energi sebanyak 1000x, dan konformasi geometris, kedua proses tersebut menggunakan piranti lunak Vega ZZ. Hasil pencarian konformasi terbaik dipilih sebagai struktur yang akan ditambatkan pada makromolekul.

Makromolekul reseptor diunduh dari situs penyedia PDB makromolekul http://www.rscb.org/pdb. Struktur makromolekul dibersihkan dari ligan menggunakan software UCSF Chimera. Kemudian molekul air dibuang, sebaliknya ditambahkan atom hidrogen dan muatan parsial Gasteiger Charges dan diberi forcefield Autodock. Minimisasi dan pencarian konformasi dilakukan sebanyak 1000 langkah. Proses tersebut menggunakan piranti lunak Vega ZZ. Data makromolekul disimpan dalam format $\mathrm{pdb}$.

Penambatan molekul dilakukan menggunakan program Arguslab 4.01. Struktur makromolekul dan ligan yang akan ditambatkan telah dioptimasi secara terpisah disimpan dalam satu folder yang sama. Hasil penambatan disimpan dalam format pdb.

\section{HASIL DAN PEMBAHASAN}

\section{A. Hasil Penelitian}

Uji Antidiabetes dengan Mekanisme Inhibisi $\alpha$ Glukosidase secara in vitro

Uji aktivitas antidiabetes dengan mekanisme inhibisi $\alpha$-glukosidase terhadap standar kuersetin dan senyawa 5, 7, 2', 5' tetrahidroksi flavan-3-ol diperoleh nilai IC $_{50}$ masing-masingnya sebesar $17,5 \mu \mathrm{g} / \mathrm{mL}$ dan $9,10 \mu \mathrm{g} / \mathrm{mL}$.

Tabel 1. Data uji aktifitas antidiabetes standar dan isolat uji

\begin{tabular}{cccc}
\hline Sampel & Kons & \% Inh & $\begin{array}{c}\text { IC50 } \\
(\boldsymbol{\mu g} / \mathbf{m L})\end{array}$ \\
\hline Blanko & & & \\
Kuersetin & 25 & 72.46 & 17.5 \\
& 12.5 & 58.0 & \\
& 6.25 & 37.29 & \\
Flavan-3- & 3.125 & 25.24 & \\
ol & 25 & 83.37 & 9.10 \\
& 12.5 & 59.43 & \\
& 6.25 & 30.52 & \\
& 3.125 & 21.26 & \\
\hline
\end{tabular}


Uji Antidiabetes dengan Mekanisme Inhibisi $\alpha$ Glukosidase secara in silico

Proses uji in silico diawali proses validasi metode, optimasi ligan dan reseptor dan terkhir baru dilakukan docking ligan-reseptor. Ligan dalam hal ini adalah sukrosa, kuersetin dan flavan-3-ol. Selengkapnya validasi native ligan, profil struktur 2D dan 3D, serta hasil docking masing-masing ligan tersebut ditunjukkan pada tabel $\mathbf{2}, \mathbf{3}$ dan $\mathbf{4}$ serta gambar 1, 2 dan 3 dibawah ini.
Tabel 2. Validasi Native Ligand 1328 ACR (Substrat $\alpha$-Glukosidase)

\begin{tabular}{|c|c|c|c|}
\hline \multicolumn{3}{|c|}{ Parameter Validasi } & RSMD \\
\hline \multicolumn{2}{|c|}{ Calculate Size } & Grid & \multirow{4}{*}{$\begin{array}{c}2,374 \\
\AA\end{array}$} \\
\hline $\mathrm{X}$ & 21,243720 & \multirow{3}{*}{0,4} & \\
\hline $\mathrm{Y}$ & 20,981007 & & \\
\hline $\bar{Z}$ & 17,354000 & & \\
\hline
\end{tabular}

Tabel 3. Struktur 2D dan 3D ligand (Sukrosa, Kuersetin dan Flavan-3-ol)

\begin{tabular}{|c|l|c|c|}
\hline No & \multicolumn{1}{|c|}{ Nama Ligan } & Struktur 2 Dimensi & $\begin{array}{c}\text { Struktur 3 Dimensi } \\
\text { (Hasil Optimasi) }\end{array}$ \\
\hline 1 & Sukrosa (Agonis) & Kuersetin (Standar) & \\
\hline 3 & Flavan-3-ol &
\end{tabular}

Tabel 4. Hasil docking (kkal/mol) dan ikatan hidrogen antara ligan dengan reseptor

\begin{tabular}{ccccc}
\hline $\begin{array}{c}\text { Senyawa } \\
\text { Uji }\end{array}$ & $\begin{array}{c}\text { Jumah } \\
\text { Ikatan } \\
\text { Hidrogen }\end{array}$ & $\begin{array}{c}\text { Jarak Ikatan } \\
(\mathbf{\AA})\end{array}$ & $\begin{array}{c}\text { Asam Amino } \\
\text { Yang } \\
\text { Berikatan }\end{array}$ & $\begin{array}{c}\text { Gugus } \\
\text { Senyawa Uji } \\
\text { yang Berikatan }\end{array}$ \\
\hline Sukrosa & 2 & 2,63 & Arg 404 & OH \\
& 2 & 3,00 & & OH \\
& & 2,98 & His 478 & OH \\
& 1 & 3,05 & & OH \\
Kuersetin & 1 & 2,51 & Asp 420 & OH \\
Flavan-3-ol & 1 & 2,88 & Asp 197 & OH \\
& 2 & 2,90 & Asp 236 & OH \\
& 1 & 2,00 & Asp 420 & OH \\
& 1 & 2,75 & & OH \\
& & 3,05 & Trp 417 & OH \\
\hline
\end{tabular}




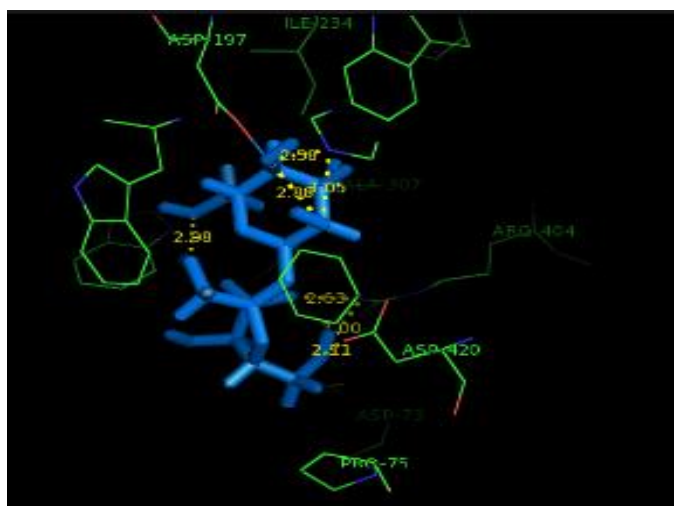

Gambar 1. Hasil visualisasi PyMol hasil docking enzim alpha glucosidase dengan sucrose (Arg 404 memiliki 2 ikatan hydrogen dengan sukrosa, His 478 2 ikatan, sedangkan ASP 4201 ikatan dan ASP 197 masing-masing dengan ikatan hydrogen)

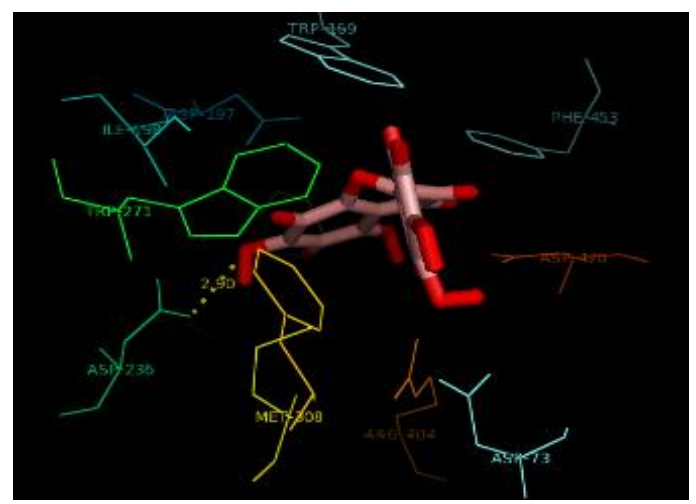

Gambar 2. Hasil visualisasi PyMol hasil docking enzim alpha glucosidase dengan kuersetin (ASP 236 memiliki 1 ikatan hydrogen dengan kuersetin)

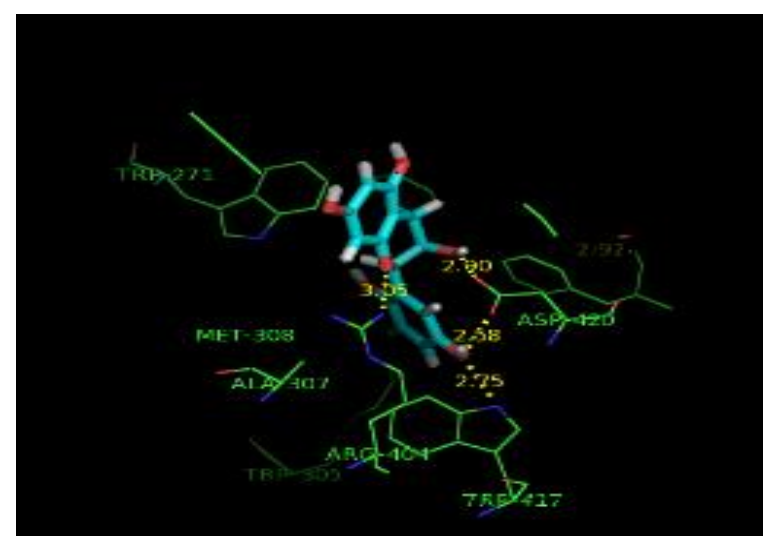

Gambar 3. Hasil visualisasi PyMol hasil docking enzim alpha glukosidase dengan Flavan-3-ol (ASP 420 memiliki 2 ikatan hydrogen, ARG 4041 ikatan hydrogen dan TRP 417 memiliki 1 ikatan hydrogen

\section{B. Pembahasan}

Uji Antidiabetes dengan Mekanisme Inhibisi $\alpha$ Glukosidase secara in vitro

Uji antidiabetes dilakukan secara in vitro menggunakan $\quad$-nitrofenil- $\alpha$-D-glukopironosa sebagai substrat. Enzim $\alpha$-glukosidase akan menghidrolisis substrat p-nitrofenil- $\alpha$-Dglukopironosa menjadi p-nitrofenol yang berwarna kuning. Aktivitas enzim $\alpha$-glukosidase diukur berdasarkan absorbansi p-nitrofenol (Basuki, et al. 2002 \& Dewi, et al. 2007).

Senyawa flavan-3-ol memiliki kemampuan menghambat aktivitas enzim $\alpha$-glukosidase menghidrolisis substrat p-nitrofenil- $\alpha-\mathrm{D}$ glukopironosa menjadi p-nitrofenol. Daya hambatnya malah lebih baik dibandingkan standar kuersetin. Hal ini diduga perbedaan pola hidroksilasi pada cincin benzena (B) dimana flavan-3-ol memiliki ikatan hidroksi pada posisi para, sedangkan kuersetin posisi ortho. Hasil ini senada dengan laporan Frengki et al (2011).

\section{Uji Antidiabetes dengan Mekanisme Inhibisi $\alpha$ - Glukosidase secara in silico}

Langkah awal dilakukan berupa validasi program ArgusLab untuk mendapat metode yang reliabel. Validasi dilakukan dengan menggunakan pilihan docking engine ArgusDock pada rentang kalkulasi sumbu x 21.243720, sumbu y 20,981007 dan sumbu z 17,354000. Metode ini memberikan nilai

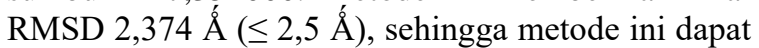
digunakan untuk melakukan proses docking. Proses validasi ini dilakukan terhadap salah satu substrat reseptor 3POC ( $\alpha$-glukosidase pada usus manusia yang berasal dari mikroorganisme Ruminococcus obeum) yang secara eksperimen telah dikenali dan diberi nama 1328 ACR.

Reseptor diketahui memiliki binding site pada residu asam amino Arg 404, Asp 197, Asp 420 dan His 478 dengan kode A5ZY13 (www.uniprot.org). Berat molekul reseptor ini adalah 156840.93 dengan jumlah asam amino penyusunnya 666. Reseptor ini telah mengalami mutasi pada residu asam amino ke 307 dari Asp menjadi Ala.

Docking dilakukan menggunakan aplikasi ArgusLab 4.01. Dari empat tempat penambatan tersebut ternyata Arg 404 menunjukkan energi bebas Gibs $(-\Delta \mathrm{G}(\mathrm{kkal} / \mathrm{mol}))$ yang paling rendah, sehingga Arg 404 juga menjadi target penambatan. Semua ligan menunjukkan nilai energi bebas Gibs negatif. Artinya ketiga senyawa tersebut mampu berikatan dengan reseptor dengan melepaskan sejumlah energi. Masing-masing memberikan nilai energi bebas Gibs 10,24 (flavan-3-ol), -7,02 (sukrosa) dan 8,95 (kuersetin) $\mathrm{kkal} / \mathrm{mol}$. 
Semakin negatif nilai energi bebas Gibs maka akan semakin stabil senyawa tersebut berikatan dengan reseptornya. Dalam hal ini flavan-3-ol memiliki affinitas yang lebih baik dibanding sukrose. Hal ini menunjukkan bahwa flavan-3-ol mampu menghambat ikatan gula (sukrose) dengan reseptornya. Demikian juga dengan kuersetin yang memiliki afinitas lebih kuat dibandingkan sukrosa.

Yang menarik dari hasil in slico ini adalah flavan-3-ol bukan hanya memiliki afinitas lebih kuat dibandingkan sukrosa, juga menunjukkan kestabilan komplek lebih baik dibandingkan kuersetin sebagai kontrol yang memang telah terbukti aktif sebagai inhibitor enzim $\alpha$-Glukosidase.

Daya hambat flavan-3-ol dan kontrol kuersetin terhadap enzim $\alpha$-glukosidase melalui uji in vitro berbanding lurus dengan hasil in silico. Kedua metode ini saling melengkapi dalam rangka penelusuran efek suatu senyawa aktif farmakologis yang telah dibuktikan melalui penelitian ini.

\section{KESIMPULAN}

Aktivitas inhibisi flavan-3-ol terhadap enzim $\alpha$-glukosidase yang sangat kuat menunjukkan potensinya yang menjanjikan sebagai kandidat obat antidiabetes.

\section{DAFTAR PUSTAKA}

Backer and Bakhuizen Van den Brink. (1963). Flora of Java, Vol 1, N. V. P. Noordhoof ofGoningen-The Nederlands

Basuki, T., et al. (2002). Evaluasi aktivitas daya hambat enzim $\alpha$-glukosidase dari ekstrak kulit batang, daun, bunga dan buah kemuning [Murraya Paniculata (L.) Jack.]. Prosiding Seminar Nasional Tumbuhan Obat Indonesia XXI. Surabaya: Fakultas Farmasi Universitas Surabaya

Cao, S-G., et al. (1998). Minor Coumarins from Calophyllum teysmannii var. inophylloide and Synthesis of Cytotoxic Calanone Derivatives. Helv. C. Acta. 81: Issue 5-8. 1404-1415

Christine. (1985). Penggunaan Tanaman Obat. Jakarta: Penerbit Buletin Farmakon

Dewi, R.T., et al. (2007). Inhibitory effect of Koji Aspergillus terreus on $\alpha$-glucosidase activity and postprandial hyperglycemia. Pakistan Journal of Biological Science, 18, 31313135.

Dharmaratne, Wijesinghe, Thevanasem. (1999). Antimicrobial activity of xanthones from
Calophyllum spesies, against methicillinresistant S. aureus (MRSA). Journal of Ethnopharmacology, 66. 339-342

Frengki. 2011. Isolasi senyawa aktif dari fraksi etil asetat kulit batang tumbuhan C. Macrophyllum Scheff. Tesis. Departemen Farmasi-UI. Depok

Heyne. (1987). Tumbuhan berguna Indonesia, Jilid III. Jakarta: Cetakan ke 1, Badan Litbang Kehutanan Jakarta. Departemen Kehutanan. Gatot Subroto. 1374-1380

Iinuma, et al. (1994). Two xanthones from root bark of Calophyllum inophyllum. Phytochemistry. 35. 527-532.

Iinuma, M., et al. (1996). Six xanthones from Calophyllum austroindicum. Phytochemistry. 43. 681-685

Ito, T., et al. (2003). Chemical constituents of Calophyllum brasiliense 2. Structure of Three New Coumarins and Cancer chemopreventive Activity of 4-Subtituted Coumarins. Journal of Natural Product, 66. 368-371.

Kirk, et al. (1999). Calanone, a novel coumarin from Calophyllum teysmannii. Tetrahedron Letter. Vol 35. No 32, 5821-5824

Ragno, R., et al. (2009) "Molecular Docking Tutorial". http://www.mmvsl.farm.unipi.it

Ratnayake, et al. (1986). Two chemically distinct groups of Calophyllum species from Sri Langka. Phytochemistry. Vol 25. 425-42

Rayes-Chilpa, et al. (2004). Cytotoxi effect of mammea type coumarins from Calophyllum brasillense. Life Science. Vol 75. 1635-1647

Soerjanegara and Lemmens, R.H.M.J. (1994). Plant Resources of Sout-East Asia 5. Prosea, Bogor: Pudoc. 114-138

Sutedja, L, 2003. Bioprospecting Tumbuhan Obat Indonesia Sebagai Sediaan Fitofarmaka Antidiabetes. Laporan Kemajuan Tahap II Riset Unggulan Terpadu, Pusat Penelitian Kimia-LIPI.

Taher, et al. (2005). A polyisoprenylated ketine from Calophyllum enervosum. Phytochemistry. 66, 723-726

Yimdjo, M. C., et al. (2004). Antimicrobial and cytotoxic agents from Calophyllum inophyllum. Phytochemistry. 65. 2789-2795 